\title{
Vaccination of Haematopoietic Stem Cell Transplant Recipients: Guidelines of the 2017 \\ European Conference on Infections in Leukaemia (ECIL 7)
}

Companion paper $2 / 2$

Prof Catherine Cordonnier ${ }^{1}, M D$, Sigrun Einarsdottir ${ }^{2}, M D$, Prof Simone Cesaro ${ }^{3}, M D$, Roberta Di

Blasi $^{4}, M D$, Prof Malgorzata Mikulska ${ }^{5}, M D$, Prof Christina Rieger ${ }^{6}, M D$, Hugues de Lavallade ${ }^{7}, M D$, Giuseppe Gallo ${ }^{8}, \mathrm{MD}$, Prof Thomas Lehrnbecher ${ }^{9}, \mathrm{MD}$, Prof Dan Engelhard ${ }^{10}, \mathrm{MD}$, Prof Per Ljungman ${ }^{11}, M D$

On behalf of the ECIL group, a joint venture of the Infectious Diseases Working Party of the European Society for Blood and Marrow transplantation (EBMT), the Infectious Diseases Group of the European Organization for Research and Treatment of Cancer (EORTC), the European Leukaemia Net (ELN) and the Immunocompromised Host Society (ICHS).

\footnotetext{
${ }^{1}$ Assistance Publique-Hopitaux de Paris (APHP), Henri Mondor Hospital, Haematology Department, and University Paris-Est Créteil, Créteil, France;

${ }^{2}$ Sahlgrenska University hospital, Sahlgrenska Academy, Göteborg, Sweden;

${ }^{3}$ Pediatric Haematology Oncology, Azienda Ospedaliera Universitaria Integrata, Verona, Italy;

${ }^{4}$ APHP, Henri Mondor Hospital, Haematology Department, France;

${ }^{5}$ University of Genoa (DISSAL) and IRCCS Ospedale Policlinico San Martino, Genova, Italy;

${ }^{6}$ University of Munich, 82110 Germering, Germany;

${ }^{7}$ King's College Hospital NHS Foundation Trust, London, UK;

${ }^{8}$ Azienda Ospedaliera Universitaria Integrata Verona, Italy ;

${ }^{9}$ Hospital for Children and Adolescents, and University of Frankfurt, Frankfurt, Germany;

${ }^{10}$ Hadassah-Hebrew University Medical Center, Jerusalem, Israel;

${ }^{11}$ Karolinska University Hospital, and Karolinska Institutet, Stockholm, Sweden.
} 
Corresponding author: Catherine Cordonnier, MD

Haematology Department

Henri Mondor University Hospital

94000 - Créteil - France

Phone: + 33149812057

Fax: +33 149812067

E-mail: catherine.cordonnier@aphp.fr

Key words: Haematopoietic stem cell transplantation, infection, vaccine, vaccination, immunization, adult, children.

Running title: Vaccination in stem cell transplant recipients

Summary's word count: 242

Manuscript's word count: 4500

Number of tables: 5

Number of references: 142 


\section{Summary}

Infection is a main concern after haematopoietic stem cell transplantation (HSCT) and a major cause of transplant-related mortality. Some of these infections are preventable by vaccination. Most HSCT recipients lose their immunity to many pathogens as soon as the first months after transplant, irrespective of the pre-transplant donor or recipient vaccinations. Vaccination with inactivated vaccines is safe after HSCT and is an effective way to reinstate protection to many pathogens, especially to those whose risk is especially increased by the transplant procedure, i.e. influenza virus and Streptococcus pneumoniae. The response to vaccines in transplant patients is usually lower than that in healthy individuals of the same age during the first months or years after transplant but improves over time to become close to normal from 2 to 3 years after transplant. However, as immunogenic vaccines have been found to induce a response in a significant proportion of the patients as early as three months after transplant, we do not recommend postponing some crucial vaccinations with inactivated vaccines until the patient has no graft-versus-host disease (GvHD) and no immunosuppressants, as patients with GvHD have higher risk of infection and are likely to benefit from vaccination. Another issue is that of providing HSCT recipients the same level of vaccine protection as healthy individuals of the same age in a given country as far as possible. Owing to the risk of vaccine-induced disease, the use of live attenuated vaccines should be limited to specific situations. 


\section{INTRODUCTION}

Haematopoietic stem cell transplant (HSCT) recipients have a major risk of infections compared to healthy individuals of the same age. Some of these infections are life threatening but preventable by vaccination. This risk is due to complex humoral and cell-mediated deficiencies evolving over time, influenced by transplant procedures and prevention and treatment of Graft-versus-Host disease (GvHD) after allogeneic HSCT and drugs received for autologous HSCT. Specific antibody levels decrease for many pathogens over the first months after transplant, e.g. S. pneumoniae ${ }^{1-4}, H$. influenzae $\mathrm{B}^{5,6}$, or measles. Between $30 \%$ and $100 \%$ of the patients lose specific humoral immunity one year after transplant. ${ }^{7-11}$

HSCT recipients are able to respond to most vaccines although to a lower extent than healthy individuals during the first months or years after transplant. ${ }^{12-14}$ The IDSA recommendation to consider HSCT recipients as 'never vaccinated' ${ }^{15}$ highlighted the need to offer a full vaccination programme according to age and country recommendations, which take into account local epidemiology.

Several international guidelines, including recommendations for HSCT recipients, have been published. ${ }^{14-16}$ In 2017, ECIL 7 decided to provide an update on vaccination of all patients with haematological malignancies, including HSCT recipients.

\section{METHODS}

The methods used for developing guidelines are reported in the companion paper. ${ }^{17}$ The literature search was carried out with the following keywords: bone marrow or haematopoietic stem cell or peripheral blood stem cell (PBSCT) or umbilical cord blood transplantation (UCBT) AND immunisation, vaccination, vaccine, immune response, donor vaccination, AND/OR S pneumoniae, $H$ influenzae, $N$ meningitidis, tetanus, diphtheria, pertussis, influenza, B hepatitis, poliomyelitis, human 
papillomavirus, varicella, zoster, measles, mumps, rubella, yellow fever, dengue, rotavirus, BCG, liveattenuated vaccines. The recommendations were graded according to the ESCMID (Appendix 1$)^{18}$.

\section{RESULTS OF THE LITERATURE REVIEW AND RECOMMENDATIONS}

\section{ANTIBACTERIAL INACTIVATED VACCINES}

\section{Streptococcus pneumoniae}

The ECIL group recommends 3 doses of pneumococcal conjugate vaccine (PCV) from 3 months after $H S C T$, followed 6 months later by either a $4^{\text {th }}$ dose of PCV in case of GVHD, or one dose of pneumococcal 23-valent polysaccharide vaccine (PPSV23).

The risk of invasive pneumococcal disease (IPD) has been estimated to be $3.8-5$ cases after autologous and 8.2-9 cases after allogeneic HSCT for 1,000 transplants, with a higher risk in case of chronic GvHD after allogeneic HSCT and total body irradiation (TBI) after autologous HSCT. ${ }^{19,20}$ However, these 15-year old data do not reflect current procedures that rarely include TBI but often include maintenance therapies.

HSCT recipients have low specific antibody titres, especially IgG2 and IgG4, and serum opsonophagocytic activity (OPA). ${ }^{1-4}$ Around 6 months after transplant, $85 \%$ of them are unprotected 21,22. Most patients are infected by vaccine serotypes. ${ }^{23,24}$

After allogeneic HSCT, the response to PPSV23 is poor, in the range of $20-30 \%$ between 6 and 12 months, and 50\% from 12 months. ${ }^{25}$ It is impaired by chronic GvHD and steroids. ${ }^{1,26,27}$ However, when administered at 12 to 18 months after 3 PCV7 doses, PPSV23 induced a response in more than $80 \%$ of the patients, including in $42 \%$ of previous PCV non-responders. ${ }^{27}$ Therefore, the administration of PPSV23 is recommended after 3 PCV13 doses to broaden the spectrum of vaccination, except in patients with GVHD in whom response is unlikely. PCV15 is currently under investigation. 
In controlled studies of PCVs during the first year of allogeneic HSCT (Table 1), PCV was safe, with very rare severe adverse events (SAE), hypothetically related to $P C V .{ }^{21,22,28-30}$ The response to 3 doses of PCV was $64-98 \%{ }^{21,22,28,30}$ and comparable when starting at 3 or at 9 months. ${ }^{21}$ Geometric mean concentrations (GMCs) of specific IgG correlated well with OPA. ${ }^{28,31}$ A fourth PCV13 dose given at 912 months still increased the GMCs. ${ }^{28}$ Patients vaccinated at 3 months may have lower antibody titres at 24 months than those vaccinated at 9 months ${ }^{21}$, but with no difference 8-11 years later and no clear benefit of one PPSV23 dose given 2-11 years later. ${ }^{32}$ Uncontrolled studies in patients vaccinated after the first year showed consistent results. ${ }^{5,6,33,34}$ After autologous PBSCT conditioned with BCNU, etoposide and melphalan, the response rate to PPSV23 at $11-12$ months was $45 \% .{ }^{35}$ The response rate to 3 PCV7 doses given at 3,6 , and 12 months was higher than $60 \% .{ }^{36}$

Because the risk of IPD starts from the time of transplantation, especially in patients with GVHD, and the patients are able to respond early, we recommend starting vaccination from 3 months with 3 doses of PCV at 1-month interval, followed around 6 months later by either 1 dose of PPSV23, or by 1 dose of PCV in case of chronic GvHD (Table 2). Although there is no safety issue in administering 1 dose of PPSV23 after a fourth dose of PCV, the benefit to be expected is probably marginal in patients with GvHD. In patients with severe hypogammaglobulinemia $(<3 g / L)$, severe GvHD, or recent ( $<6$ months) rituximab administration, the response may be low, and they may benefit from alternatives (i.e. antibacterials, immunoglobulins) to vaccination until improvement. Given the lack of large data sets, no recommendation can be given for subsequent boosts. The assessment of antibody titres should help in defining the best individual option at a given time.

\section{Haemophilus influenzae B (HiB)}

The ECIL group recommends 3 doses of HiB vaccine at 1 month interval from 3 months after HSCT, or 3 doses of a combined Diphtheria-Tetanus-Pertussis-HiB vaccine from 6 months. 
$\mathrm{HiB}$ may cause pneumonia, sinusitis, and bacteraemia early after transplantation ${ }^{37,38}$ owing to unprotective titres of capsular antibodies..$^{6,39,40}$

The response rate to HiB conjugate vaccines was $80-95 \%$, after 2 or 3 doses ${ }^{6,41-44}$, even when given from 4 months ${ }^{40}$, after non-myeloablative $\mathrm{HSCT}^{5}$ or UCBT ${ }^{34}$ and was hardly affected by GvHD. ${ }^{40,45-47}$ The benefit of pre-harvest vaccination reported in allogeneic marrow transplant recipients ${ }^{41}$ seems marginal for autologous PBSCT. ${ }^{48}$

Considering the early onset of most $\mathrm{HiB}$ infections and that patients may respond early, we recommend starting vaccination (3 doses at 1-month interval) from 3 months (Table 2). Whether additional boosters are needed is unknown and the assessment of specific antibodies may inform this decision.

Given the widespread HiB vaccination of healthy children, nontypeable $H$ influenzae (NTHi) infections are now predominant. ${ }^{49}$ Data on Hi serotypes are warranted after HSCT and NTHi vaccines should be assessed in the future.

\section{Neisseria meningitides}

The ECIL group recommends meningococcal vaccination in accordance to country recommendations. Although invasive meningococcal disease (IMD) has been reported after $\mathrm{HSCT}^{50}$, there is a dearth of vaccine data. Between 8 and 20 months after transplant, $86-90 \%{ }^{51,52}$ and $38-96 \%{ }^{51,53}$ of the patients were unprotected for serogroups $C$ and $A$.

Different types of vaccines exist in Europe: tetravalent (A, C, Y, W135) conjugate (MCV-4), monovalent $\mathrm{C}$ conjugate (MCV-C), and two anti-B vaccines (MenB). In children, 3 doses of MCV-4 administered from 12 months after autologous HSCT or 18 months after allogeneic HSCT provided a $100 \%$ response rate. ${ }^{52}$ One dose was poorly immunogenic..$^{53}$

Although the response to 2 doses of MenB was over $75 \%$ in other immunocompromised patients ${ }^{54}$, studies after HSCT are lacking. Nevertheless, as serogroup B recently caused 74\% of IMD in Europe ${ }^{55}$, we recommend vaccination against serotypes B and C from 6 months (table 2). 


\section{Tetanus and diphtheria}

The ECIL group recommends 3 doses of D-T vaccine at 1-2-months interval, from 6 months after HSCT.

Half of the patients lose their protection during the first year of transplantation, irrespective of the donor's and recipient's serology ${ }^{56}$. The response to tetanus vaccine given from day 50 , usually at $6-$ 12 months, is $85-100 \%$ after 3 doses ${ }^{42,56-58}$. It is slightly affected by GvHD ${ }^{42,57}$ or conditioning intensity ${ }^{5}$ but may be lower after UCBT. ${ }^{34}$ The response is comparable after autologous HSCT, except in case of rituximab given before and/or after transplantation. ${ }^{44,59,60}$ The response rate to diphtheria vaccine was $70-100 \%$ after 3 doses given from 3 months after allogeneic $\mathrm{HSCT}^{33,42,57,59}$ and $1.5-10$ years after autologous HSCT. ${ }^{59,60}$ Although the vaccine(s) containing high doses of diphtheria toxoid (DT) are not recommended for healthy adults owing to an increased risk of $A E$, these DT vaccines could provide better protection than low-dose toxoid (Td) vaccines after allogeneic $\mathrm{HSCT}^{57}$ (table 2). Therefore, we recommend DT irrespectively of age.

\section{Bordetella pertussis}

The ECIL group recommends to consider the addition of pertussis toxoid to each dose of D-T vaccine. Despite the reappearance of pertussis in adults ${ }^{61}$, the data regarding whether pertussis causes severe infections after HSCT are limited. However, most HSCT recipients have decreased antibody titres $^{34,60}$ and could be unprotected..$^{62-65}$

All anti-pertussis vaccines are combined at least with tetanus-diphtheria. The vaccines licensed for children contain higher amounts of the pertussis toxoid ( $25 \mu \mathrm{g}$; DTaP) than those licensed for adults (2.5-8 $\mu \mathrm{g} ;$ Tdap). One dose of Tdap provides very low response rates. ${ }^{60,66}$ After 2 or 3 doses of Tdap in adults and of DTap in children, a median of 17 months after UCBT, all children and 54\% of the adults, with no GvHD, developed $a \geq 2$-fold rise in the antibody. ${ }^{34}$ Although the response to pertussis vaccine 
may be low and not persistent ${ }^{57}$, we recommend this vaccination, especially to participate in maintaining herd immunity (table 2).

\section{ANTIVIRAL INACTIVATED VACCINES}

\section{Inactivated influenza vaccine (IIV)}

The ECIL group recommends one dose of seasonal IIV, yearly at the beginning of flu season, and as long as the patient is judged to be immunocompromised.

Influenza infection is frequent and may be severe in HSCT recipients. One-third of infected patients may develop lower respiratory tract disease, with high mortality rates despite antivirals ${ }^{67-69}$. The clinical efficacy of one dose of trivalent IIV has been shown in a cohort of 177 HSCT recipients vaccinated 6 months after transplantation. ${ }^{70}$

The response rates were $10-40 \%$ within 6 months ${ }^{71-73}$ and improved to $10-72 \%$ with the seasonal ${ }^{35,73-76}$, and $37-84 \%$ with pandemic adjuvanted ${ }^{77-79}$ or non-adjuvanted ${ }^{80} \mathrm{H} 1 \mathrm{~N} 1$ vaccines after 6 months, to become close to the response of healthy individuals at 2 years. ${ }^{72,73,75,79,80}$ The response was negatively affected by lymphopenia ${ }^{72,81}$, hypogammaglobulinemia ${ }^{79,81}$, GvHD, immunosuppressants ${ }^{73,79,81}$, and rituximab..$^{80}$ No safety issue was observed.

Most approaches failed to improve this response:

(1) An adjuvanted IIV was not more immunogenic than a non-adjuvanted vaccine after allogeneic $\mathrm{HSCT}^{73}$

(2) The benefit of 2 doses vs. one dose was suggested both for seasonal ${ }^{72}$ and $\mathrm{H} 1 \mathrm{~N} 1$ vaccines $^{77-79,82}$ but not found in a randomised study after allogeneic HSCT. ${ }^{75}$

(3) A high-dose $(60 \mu \mathrm{g})$ antigen trivalent IIV - not available in Europe - was more immunogenic but induced more injection-site reactions than a standard-dose $(15 \mu \mathrm{g})$ vaccine after allogeneic $\mathrm{HSCT}^{83}$. 
(4) GM-CSF administered with the seasonal vaccine improved the response to influenza B but not to $\mathrm{H} 1 \mathrm{~N} 1$ or $\mathrm{A} / \mathrm{H} 3 \mathrm{~N} 2 .^{76}$

(5) Donor or recipient pre-transplant vaccination improved seroprotection during the first 2 months but not the response to later vaccination. ${ }^{74}$

The clinical benefit and safety of IIV after HSCT largely support the vaccination (Table 2). A second dose might be beneficial in patients cumulating factors of poor response (GvHD, lymphopenia) or during outbreaks in patients vaccinated within 6 months of transplantation. HSCT recipients should benefit from additional measures (e.g. respiratory isolation, rapid diagnostic tests in case of symptoms, and post-exposure antivirals). ${ }^{84}$

The intranasal influenza live-attenuated vaccine (LAV) is contra-indicated after HSCT.

\section{Inactivated poliomyelitis vaccine (IPV)}

The ECIL group recommends 3 doses of IPV given at 1-2-month interval from 6-12 months after HSCT. After HSCT, $30-100 \%$ of patients between 6-12 months lost their immunity to polio.$^{85-88}$ Owing to the risk of post-vaccinal poliomyelitis with the oral LAV, only IPV should be used (DIII). The response to 3 doses of IPV given from 6 months was $80 \%-100 \%$, affected slightly by GvHD $33,42,57,58,86,89$, and long lasting, except in children transplanted before the age of 10 years (Table 2). ${ }^{90}$

\section{Hepatitis B virus (HBV) vaccine}

The ECIL group recommends that patients who were negative for HBV before transplantation and patients who were vaccinated before transplant but lost their immunity at 6 months should be vaccinated from 6-12 months after HSCT according to country recommendation.

The ECIL group published guidelines for the management of viral hepatitis, including HBV, in 2016. ${ }^{91}$ There are three different goals of HBV vaccination after HSCT: 
a) To offer a similar protection as the healthy individuals according to country recommendations, even in patients vaccinated before transplant but who may lose their immunity

b) To protect the recipient from getting HBV from an anti-HBc-positive donor

c) To decrease the risk of reverse seroconversion in recipients previously HBV-infected

Although the donor can transfer his/her HBV immunity, and the recipient may have been vaccinated before the transplantation, half of the recipients lose seroprotection within 6 months ${ }^{92,93}$, and $90 \%$ were unprotected at 5 years. ${ }^{94}$

After 3 doses of HBV vaccine, started at a median of 23 months after allogeneic HSCT, seroconversion was $64 \%{ }^{93}$, impaired by age and chronic GvHD but not by T-cell depletion or rituximab given at a median of 16 months before. The benefit of an increased antigen dose $(40-80 \mu \mathrm{g})$ is unknown after HSCT.

An anti-HBc positive donor can transmit HBV to the recipient, even if negative in nucleic-acid testing. ${ }^{91}$. In this case, the ECIL group recommended, on the basis of a retrospective study, ${ }^{95}$ vaccinating the recipient before transplantation. ${ }^{91}$ Although not assessed after HSCT, an accelerated schedule of vaccination (day $0,10,21$ ) may elicit a $70 \%$ response rate in healthy individuals (Table 2 ). ${ }^{96}$ In previously HBV-infected recipients, in addition to antivirals ${ }^{91}$, vaccination might prevent reverse seroconversion..$^{97,98}$

Finally, a regular reassessment of anti-HBs titres is recommended from 6 months after HSCT, and 1-2 months after 3 vaccine doses. As the response is lower than in healthy individuals, non-responders (anti-HBs $<10 \mathrm{mIU} / \mathrm{mL}$ ) should be identified to consider a second series later on, although its benefit is uncertain.

\section{Human papillomavirus (HPV)}


The ECIL group recommends to follow guidelines for general population in each country from 6-12 months after transplant.

HSCT recipients may develop HPV-associated tumours ${ }^{99}$, especially in case of chronic GvHD. ${ }^{100} \mathrm{HPV}$ vaccination is recommended for healthy adolescents or young adults to prevent HPV-related malignancies in most countries. Twenty previously unvaccinated children received 3 doses of the quadrivalent vaccine from 6-12 months after HSCT with only minor AE. The seroconversion rate was close to $100 \% .{ }^{101}$ Although there is no large-scale data on vaccine efficacy after HSCT, no safety issues are expected ${ }^{102,103}$ and HPV vaccination should be beneficial in the young patients (Table 2). Whether it is beneficial in older recipients remains to be assessed.

\section{General issues on safety of inactivated vaccines after HSCT}

Only prospective trials can properly assess AE and SAE. We mainly focused our safety review on pneumococcal and influenza vaccines and those assessed after HSCT in larger prospective trials. After IIV, mild injection-site reactions are common and may increase with higher dosage per shot ${ }^{83}$ but resolve quickly. In trials including healthy controls, there is no evidence that AE or SAE were more frequent after $\mathrm{HSCT}^{79,82,104,105}$ and one study even suggested a decreased incidence of $\mathrm{AE}$ after intradermal injection of IIV as compared to healthy controls. ${ }^{105}$ After anti-pneumococcal vaccination, AEs observed in HSCT recipients did not seem to be more frequent than in healthy individuals. In HSCT children, there were more local or systemic reactions after the third ${ }^{22}$ or the fourth ${ }^{28}$ PCV dose.

In summary, AE or SAE after inactivated vaccines are not different in nature, severity, duration, or frequency in HSCT patients and healthy individuals and should not limit vaccination. Additionally, in prospective trials, there was no evidence that vaccination triggers or worsens GvHD..$^{28,78}$

\section{LIVE-ATTENUATED VACCINES}


LAVs are, in general, contraindicated in immunocompromised patients owing to the risk of vaccinetransmitted disease ${ }^{106}$ However, when there are no inactivated alternatives, they may be carefully considered based on the risk/benefit balance.

The ECIL group recommends varicella and MMR LAV from 24 months, only in seronegative patients with no GvHD, no immunsuppressants, no relapse, and no recent administration of immunoglobulins.

\section{Varicella-zoster virus (VZV) vaccines}

VZV infections may be life threatening after HSCT. The risks are primary varicella infection (chickenpox) in seronegative patients and shingles and postherpetic neuralgia in seropositive patients. Acyclovir/valacyclovir prophylaxis given for 1 year after allogeneic HSCT - longer in case of GvHD - and for 3-6 months after autologous HSCT is effective, cheap, and safe for preventing reactivation in seropositive patients. ${ }^{107}$

At the ECIL 7 meeting, only LAVs against VZV were available: the varicella vaccines (LAVV), and the zoster vaccine (LAZV) which contains much higher titres of viruses than the LAVV. Fatal disseminated vaccine-induced VZV infections have been occasionally reported both with LAVV after HSCT ${ }^{108}$ or intensive chemotherapy, ${ }^{109}$ and with LAZV, even 6 months after stopping chemotherapy. ${ }^{110}$

Several observational studies with LAVV have been performed in seronegative HSCT recipients, with 1 to 3 doses given from $3^{111}$ to $4-5$ months ${ }^{112}$ after autologous HSCT, and from $12-24$ months ${ }^{113}$ in selected allogeneic HSCT recipients ${ }^{114}$ or for zoster prophylaxis in seropositive recipients. ${ }^{115}$ No SAE was reported. However, some patients developed vaccine-related varicella. ${ }^{112,114}$ The response rate was around $65 \%{ }^{111,112,114}$ with some clinical protection, without a clear benefit of a second dose. ${ }^{111-}$

${ }^{114}$ This benefit may, however, be different in VZV seronegative or seropositive patients before transplantation. As there is no inactivated alternative, we recommend LAVV in carefully selected 
seronegative patients for varicella prevention. Patients should be informed of the risk of varicella-like rash within three weeks, to receive antivirals if necessary.

Two retrospective studies were performed with the LAZV administered at a median of 21-27 months. ${ }^{116,117}$ The vaccine was safe and the studies suggested a reduced incidence of VZV infection 116,117. Additionally, a recent study, not available at time of ECIL 7, showed that LAVZ was safe when given from 24 months after autologous HSCT in myeloma patients receiving lenalidomide ${ }^{118}$, although $14 \%$ of the patients developed upper respiratory tract infections of unknown origin. Recently, two inactivated zoster vaccines have been developed. A subunit-adjuvanted zoster vaccine is approved for prevention of shingles in adults over 50 years. ${ }^{119}$ Autologous seropositive HSCT recipients who received 3 doses from day 50 developed good and persistent responses but without reduction of herpes zoster. ${ }^{120} \mathrm{~A}$ heat-treated, zoster vaccine (V212) was shown to be poorly immunogenic after allogeneic $\mathrm{HSCT}^{121}$, but it reduced the incidence of herpes zoster vs. placebo after autologous HSCT ${ }^{122}$. This latter vaccine can be administered much earlier than LAVZ.

Given the close availability of inactivated vaccines and since antiviral prophylaxis is effective and safe, we consider that inactivated vaccines should be preferred to LAVZ. Additional data are needed in allogeneic HSCT.

\section{Measles, Mumps, Rubella (MMR)}

Although MMR vaccines are mostly combined, the concerns raised by each of these viruses are different. Measles may be life-threatening ${ }^{123-125}$ and the decreased coverage in healthy children led to outbreaks worldwide. Mumps or rubella infections are not life-threatening but a pregnant HSCT recipient may transmit rubella to her baby. The probability of becoming seronegative to measles, mumps and rubella 5 years after allogeneic $\mathrm{HSCT}$ is $60 \%, 73 \%$, and $52 \%$, respectively, ${ }^{8}$ and it is higher after vaccination than after natural infection ${ }^{7,8,10,124}$. Several open studies assessed MMR vaccines ( 1 
or 2 doses), mostly from 24 months after transplantation in children $7,33,34,52,57,70,126$ and adults without GvHD and immunosuppressants. ${ }^{7,34,124}$ Vaccination was started earlier (9-18 months) during a Brazilian outbreak, including in patients receiving low-grade immunosuppression. ${ }^{124}$ No SAE was reported. The response rates were $65-100 \%$ for measles, $50-87 \%$ for mumps, and $75-100 \%$ for rubella. In a regular setting, the group recommends that the vaccination be restricted to seronegative patients filling the conditions mentioned in table 3. In large community outbreaks, vaccination also without immunity testing or in seropositive individuals can be considered balancing the potential benefits and risks to the patient's situation including the time from transplant, age, and previous vaccination history. Patients with ongoing GVHD and/or immunosuppression should not be vaccinated.

\section{Yellow fever (YF) vaccine}

YF vaccination may be required for patients living or travelling in endemic areas. In healthy individuals, YF vaccine can cause a life-threatening disease. ${ }^{127}$ After HSCT, the risk/benefit ratio of vaccination should be cautiously weighed. Patients should be discouraged from travelling in endemic areas during the first years after transplant. Some carefully selected patients (no immunosuppression for 2 years, no active GvHD, normal CD4 counts and IgG levels) were vaccinated at a median of 3 to 9 years after transplantation, with no SAE. ${ }^{128-130}$ Most patients responded. HSCT recipients who themselves, or whose donors, were vaccinated before transplant may retain protection years after transplant ${ }^{129,131}$, suggesting to test these patients before they travel to endemic areas.

\section{Other LAVs}

Rotavirus vaccines can lead to severe diarrhoea in immunocompromised infants ${ }^{132}$ and are contraindicated after HSCT. BCG is also contraindicated owing to the risk of disseminated disease. There are no data on dengue or rabies vaccine after HSCT. 


\section{SPECIFIC ISSUES ANALYSED BY THE GROUP}

\section{Should we have different vaccination programmes after different HSCTs?}

Although the infection risks are lower after autologous than allogeneic HSCT, the same revaccination programmes are generally proposed. However, most studies on autologous HSCT were done before the era of rituximab and not in myeloma patients representing a large proportion of today's autologous HSCT population. Vaccination schedules should be reassessed based on current transplant procedures. Two recent publications, not available at time of ECIL 7, show that vaccination with inactivated vaccines under lenalidomide therapy after autologous HSCT is safe ${ }^{122,133}$ and efficient ${ }^{133}$.

Until 2000, most allogeneic HSCTs were transplanted from HLA-identical siblings with myeloablative conditioning. Nowadays, transplant cohorts are more heterogeneous, and some subgroups are not represented enough in studies to develop specific recommendations. However, GvHD remains the main driver of immune recovery ${ }^{134}$, but its negative impact, although documented in some vaccines, is marginal for the immunogenic ones. As patients with GvHD are at higher risk of infections, they might benefit more from vaccine protection, and prospective studies did not report worsening of GvHD after vaccination. On the other hand, the longer we wait after transplant, the better the vaccine response. ${ }^{72,73,75,79,80}$ Therefore, on the basis of a poor expected response in case of low CD4+ $(<200 / \mathrm{cm}){ }^{79}$ or $\mathrm{CD} 19+{ }^{57}$ cell counts, some centres delay vaccination until the patient fulfils the biological criteria they consider as markers of full immune recovery. However, there are no data to support any specific lymphocyte level for starting vaccines, and delaying the vaccination knowing that the patient can respond well, especially to T-cell dependent vaccines, early after transplant $21,25,58$ increases the at-risk period for the patient. Therefore, although a lower response can be sometimes expected, we recommend not delaying vaccination except in specific situations listed below. 


\section{Should some HSCT recipients be transiently or definitely excluded from vaccination programmes?}

Patients with severe GvHD or hypogammaglobulinemia are usually excluded from vaccine studies because they are unlikely to respond. Although gammaglobulin titres $<4 \mathrm{~g} / \mathrm{L}$ decreased the response to PCV7, the response rate was still $38 \%{ }^{21}$, suggesting a potential benefit. However, in case of severe hypogammaglobulinemia $(<3 \mathrm{~g} / \mathrm{L})$, alternatives should be considered until recovery. There are no data on patients receiving immunoglobulins.

Infused immunoglobulins could inhibit viral replication and consequently impair response to LAV. ${ }^{135}$ In this case, even if the patient fulfils other precautionary criteria for LAV, these vaccines should not be administered at least 3 months and ideally 8 months after the last immunoglobulin infusion, ${ }^{136} \mathrm{As}$ the response to LAV can be impaired by circulating immunoglobulins, it is recommended that the vaccine response be checked in order to consider an additional dose.

Rituximab induces immediate and long-term B-cell depletion, with prolonged hypogammaglobulinemia in $20-30 \%$ of the patients. ${ }^{137}$ Rituximab is widely used before and after autologous HSCT for B-cell lymphoma and in allogeneic HSCT for conditioning, EBV reactivation, or GvHD. Rituximab strongly impairs the vaccine response after allogeneic $\mathrm{HSCT}^{6,53,80}$ even as long as 28 months later ${ }^{53}$ and in case of conjugate vaccines. ${ }^{6}$ Autologous HSCT recipients vaccinated $6-8$ months after the last dose of rituximab demonstrated acceptable, although impaired, responses with T-cell dependent (e.g. tetanus, PCV), but not with T-cell independent, antigens (e.g. PPSV23). ${ }^{6,138}$ After autologous and allogeneic HSCTs, we recommend that vaccination be delayed at least for 6 months after the last dose of rituximab and the antibody response be assessed if necessary, as it is uncertain. Similar issues are expected with other anti-B monoclonal antibodies.

\section{Should we assess individual vaccine responses in HSCT recipients?}


Routine antibody titre assessment is futile when the expected response is close to $100 \%$ but can be useful to evaluate the need for certain vaccines (e.g. HBV at 6 months after transplant, MMR and LAVV at 24 months after transplant), to decide the need for vaccination or for a second dose or series in the presence of predictors of poor response (e.g. severe GVHD, rituximab), and to decide on booster administration during long-term follow-up (e.g. HiB at 5-10 years after the initial series, DTP every 3-5 years). Pneumococcal antibodies can be assessed at 24 months, although the practical consequences of such assessments - boost, or full revaccination program - are to be prospectively evaluated.

\section{Should the donor be vaccinated before donation?}

The donors should be vaccinated according to age and country recommendations for healthy individuals. Additional vaccination just before harvest is an appropriate strategy to improve the response of the recipient by transferring antigen-reacting T-cells (Table 4). ${ }^{139}$ However, it raises feasibility and ethical issues when proposed only for the purpose of donation. Moreover, the benefit only exists for T-cell dependent vaccines ${ }^{30,42,140,141}$ and is transient. ${ }^{30}$ Therefore, we do not recommend preharvest vaccinations, except for HBV vaccine in previously mentioned situations. ${ }^{91}$ LAV vaccines are contra-indicated four weeks before donation owing to the risk of vaccine-disease transmission even though the duration of vaccine-induced viremia is shorter for some LAVs. ${ }^{15}$

\section{SPECIFIC CONSIDERATIONS FOR THE FAMILY AND CLOSE CONTACTS OF TRANSPLANT}

\section{RECIPIENTS}

To avoid infection transmission to the patient, individuals in close contact with HSCT recipients should be either naturally immunised or vaccinated according to country recommendations for their age, especially against VZV and MMR, and additionally receive IIV yearly. These and other 
recommendations, contraindications, and precautions for the family and close contacts are reported in Table 5.

Recommendations for vaccination of health-care workers in haematology wards are presented in the companion paper. ${ }^{17}$

\section{AREAS FOR FUTURE RESEARCH}

The diversity in transplant procedures is increasing and HSCT is expanding to many countries, which may have specific epidemiologies of diseases preventable by vaccination. The ECIL group clearly supports prospective studies and recommends that subgroups (e.g. haploidentical or UCBT recipients) be specifically assessed for their vaccine response. The impact of anti-B monoclonal antibodies before and after transplant should be further evaluated. The optimal long-term programme should also be explored, and new vaccines should be assessed. The use of combined vaccines should be studied, especially in children, to decrease the number of injections and visits.

\section{CONCLUSION}

HSCT recipients respond to vaccines. Inactivated vaccines after HSCT are safe and a rigorous vaccination programme should be offered to all allogeneic and autologous HSCT recipients. Postponing vaccination should be restricted to very specific situations. The programme should take in account the risks in a specific community. Vaccines may save lives and avoid unnecessary hospitalisations. 


\section{Contributors}

$\mathrm{CC}$ and PL recruited the experts and compiled the recommendations. All authors were involved in the literature search, development of recommendations and conception of the manuscript. All authors revised the manuscript and gave final approval.

\section{Role of the funding source}

The ECIL 7 meeting (21-23 september, 2017) was supported by unrestricted grants from Astellas, Basilea, Chimerix, Clinigen, Gilead, MSD, Pfizer, and Shire. None of these pharmaceutical companies had any role in the selection of experts and the scope and purpose of the guidelines, or the collection, analysis, and interpretation of the data and edition of the guidelines.

\section{Declaration of interests}

CC has received grants from Merck and Astellas and has been a scientific adviser for Merck. RDB has received personal fees from Gilead and Merck. MM has been a scientific adviser for Biotest and has received payment for lectures and travel expenses from MSD, Janssen, Pfizer and Astellas, and has received travel fees from Gilead. TL has received grants from Gilead, and non-financial support and personal fees from Gilead, Astellas, MSD and Basilea. PL has received grants from Merck and Astellas and has been a scientific adviser for Merck. SC, HDL, SE, GG, CK and DE declare that they have no conflict of interests.

\section{Acknowledgments}

We thank J Peter Donnelly and Rafael Duarte for chairing the session at the ECIL-7 meeting.

We also thank the staff of GL Events, Lyon, France, for organising the meeting. 


\section{Meeting participants}

We thank the participants to the ECIL 7 meeting: Murat Akova, Ankara, Turkey ; Mahmoud Aljurf, Riyadh, Saudi Arabia; Diana Averbuch, Jerusalem, Israel; Anne Bergeron, Paris, France; Nicole Blijlevens, Nijmegen, The Netherlands; Aida Botelho de Sousa, Lisboa, Portugal; Alessandro Busca, Torino, Italy; Thierry Calandra, Lausanne, Switzerland; Simone Cesaro, Verona, Italy; Catherine Cordonnier, Créteil, France; Roberto Crocchiolo, Milan, Italy; Julien De Greef, Brussels, Belgium; Rafael de la Camara, Madrid, Spain; Hugues de Lavallade, London, UK; Roberta Di Blasi, Roma, Italy and Creteil, France; Peter Donnelly, Nijmegen, The Netherlands; Lubos Drgona, Bratislava, Slovakia; Rafael Duarte, Madrid, Spain; Sigrun Einarsdottir, Göteborg, Sweden; Hermann Einsele, Wursburg, Germany; Giuseppe Gallo, Verona, Italy; Hildegard Greinix, Graz, Austria; Raoul Herbrecht, Strasbourg, France; Joshua Hill, Seattle, US; Petr Hubacek, Prague, Czech republic; Csaba Kassa, Budapest, Hungary; Galina Klyasova, Moscow, Russia; Sylwia Koltan, Bydgoczcz, Poland; Thomas Lehrnbecher, Frankfurt, Germany; Per Ljungman, Stockholm, Sweden; Olivier Lortholary, Paris, France; Jens Lundgren, Copenhagen, Denmark; Johan Maertens, Leuven, Belgium; Rodrigo Martino, Barcelona, Spain; Georg Maschmeyer, Postdam, Germany; Sibylle Mellinghoff, Koln, Germany; Malgorzata Mikulska, Genoa, Italy; David Navarro, Valencia, Spain; Anna Maria Nosari, Monza, Italy; Livio Pagano, Roma, Italy; Karlis Paukssen, Uppsala, Sweden; Olaf Penack, Berlin, Germany; Zdenek Racil, Brno, Czech Republic; Christine Robin, Créteil, France; Emmanuel Roilides, Thessaloniki, Greece; Montserrat Rovira, Barcelona, Spain; Monica Slavin, Melbourne, Australia; Jan Styczynski, Bydgoszcz, Poland; Anne Thiebaut, Grenoble, France; Claudio Viscoli, Genoa, Italy; Katherine Ward, London, UK; Christine Wenneras, Göteborg, Sweden. Representatives of companies supporting ECIL: Laurence Dubel, Astellas; Liz Mills, Clinigen; Markus Rupp, MSD; Sonia Sanchez, Gilead; Stefan Zeitler, Basilea. 
Table 1: Main controlled studies assessing the efficacy of pneumococcal conjugate vaccines (PCV) during the first year after allogeneic haematopoietic stem cell transplant

\begin{tabular}{|c|c|c|c|c|c|}
\hline Reference & Vaccine & $\begin{array}{l}\text { No. Pts } \\
\text { (evaluable) } \\
\text { Age }\end{array}$ & $\begin{array}{c}\text { Study design and } \\
\text { immunisation schedule }\end{array}$ & $\begin{array}{l}\text { Criteria for } \\
\text { response }\end{array}$ & Percentage of responders and comments \\
\hline $\begin{array}{l}\text { Molrine et } \\
\text { al. }{ }^{30}\end{array}$ & PCV7 & $\begin{array}{l}96(65) \\
2-64 y\end{array}$ & $\begin{array}{l}\text { Three doses at } 3,6 \text {, and } 12 \\
\text { months } \\
\text { (+/- donor vaccination by } \\
\text { randomisation) }\end{array}$ & $\begin{array}{l}\geq 0.5 \mu \mathrm{g} / \mathrm{mL} \\
\quad \text { for all } 7 \\
\text { serotypes }\end{array}$ & $\begin{array}{l}\text { At } 13 \text { months: } 64-75 \% \\
\text { Benefit of donor vaccination for response to the first } 2 \text { doses, not for } \\
\text { the third }\end{array}$ \\
\hline $\begin{array}{l}\text { Kumar et al. } \\
140\end{array}$ & PCV7 & $\begin{array}{l}64(44) \\
\geq 18 y\end{array}$ & $\begin{array}{l}\text { Donor/recipient pairs } \\
\text { randomised for either PPS } 23 \text { or } \\
\text { PCV7: } 1 \text { preharvest dose to the } \\
\text { donor, } 1 \text { dose of the same } \\
\text { vaccine to the recipient at } 6 \\
\text { months. Assessment at } 6 \text { and } \\
12 \text { months for PCV7 antigen } \\
\text { antibodies }\end{array}$ & $\begin{array}{c}\geq 0.35 \mu \mathrm{g} / \mathrm{mL} \\
\text { for } \geq 1 \text { serotype }\end{array}$ & $\begin{array}{l}\text { Better immunogenicity of PCV7 vs. PPSV } 23 \\
\text { At } 6 \text { months: } 38.6 \% \text { vs. } 0 \% \\
\text { At } 12 \text { months: } 90.9 \% \text { vs. } 55.6 \%\end{array}$ \\
\hline $\begin{array}{l}\text { Meisel et al. } \\
22\end{array}$ & PCV7 & $\begin{array}{l}53(43) \\
1-16 y\end{array}$ & $\begin{array}{l}3 \text { doses at } 1 \text {-month interval } \\
\text { from } 6 \text { to } 10 \text { months }\end{array}$ & $\begin{array}{l}\geq 0.5 \mu \mathrm{g} / \mathrm{mL} \\
\quad \text { for all } 7 \\
\text { serotypes }\end{array}$ & $55.8 \%$ after 2 doses, $74.4 \%$ after 3 doses \\
\hline $\begin{array}{l}\text { Cordonnier } \\
\text { et al. }{ }^{21}\end{array}$ & PCV7 & $\begin{array}{c}158(114) \\
5-65 y\end{array}$ & $\begin{array}{l}3 \text { doses, at } 1 \text {-month interval. } \\
\text { Randomisation for starting } \\
\text { early ( } 3,4,5 \text { months) or late }(9 \text {, } \\
10,11 \text { months) after HSCT }\end{array}$ & $\begin{array}{l}\geq 0.15 \mu \mathrm{g} / \mathrm{mL} \\
\quad \text { for all } 7 \\
\text { serotypes }\end{array}$ & $\begin{array}{l}\text { Response after early vaccination was not inferior to late vaccination: } \\
79 \% \text { vs. } 82 \% \text {. } \\
\text { Chronic GvHD and donor age impaired the response } \\
\text { At } 24 \text { months after transplant: GMCs and response rates were lower } \\
\text { in the early group }\end{array}$ \\
\hline $\begin{array}{l}\text { Cordonnier } \\
\text { et al. }{ }^{28}\end{array}$ & PCV13 & $\begin{array}{l}251(207) \\
2-71 y\end{array}$ & $\begin{array}{l}\text { Open study: } 3 \text { doses, at } 1- \\
\text { month interval, from } 4 \text { months, } \\
\text { then a } 4^{\text {th }} \text { dose } 6 \text { months after } \\
\text { the } 3^{\text {rd }} \text { dose }\end{array}$ & $\begin{array}{l}\text { IgG GMFR and } \\
\geq 0.35 \mu \mathrm{g} / \mathrm{mL} \\
\text { for all } 13 \\
\text { serotypes }\end{array}$ & $\begin{array}{l}\text { GFMR significantly increased from baseline to after the } 3^{\text {rd }} \text { dose: } \\
\text { Response rate } \geq 0.35 \mu \mathrm{g} / \mathrm{mL}: 89.7 \%-98.0 \% \\
\text { Positive correlation between IgG GMCs and OPA GMTs } \\
\text { The GMCs still increased after the } 4^{\text {th }} \text { dose } \\
\text { No difference between myeloablative and non-myeloablative } \\
\text { conditioning regimens }\end{array}$ \\
\hline
\end{tabular}


GMC: Geometric mean concentration

GMFR: Geometric mean fold rises

OPA: Opsonophagocytic activity

GMT: Geometric mean titres

PCV: Pneumococcal conjugate vaccine 
Table 2: ECIL 7 recommendations for vaccination of HSCT recipients with inactivated vaccines

\begin{tabular}{|c|c|c|c|}
\hline Vaccine & $\begin{array}{c}\text { Recommendation and grading in } \\
\text { allogeneic HSCT }\end{array}$ & $\begin{array}{c}\text { Recommendation and grading in } \\
\text { autologous HSCT }\end{array}$ & Paediatric specificities \\
\hline $\begin{array}{l}\text { 13-valent pneumococcal } \\
\text { conjugate vaccine (PCV13) } \\
\left(L^{*}\right)\end{array}$ & $\begin{array}{l}\text { From } 3 \text { months after transplant: } 3 \text { doses of } \\
\text { PCV13 (or subsequent, broader spectrum, } \\
\text { conjugate vaccines) at 1-month interval (A I). } \\
\text { In case of chronic GVHD, considering the low } \\
\text { response to PPSV23, an additional dose of } \\
\text { PCV instead of a dose of PPSV23 is } \\
\text { recommended } 6 \text { months after the } 3^{\text {rd }} \text { dose of } \\
\text { PCV (B II u). }\end{array}$ & $\begin{array}{l}\text { Same initial schedule as for allogeneic } \\
\text { HSCT: } 3 \text { doses of PCV13 given from } 3 \\
\text { months after transplant, at 1-month } \\
\text { interval (A I). }\end{array}$ & $\begin{array}{l}\text { The same schedule is recommended } \\
\text { in children and adults. Children } \\
\text { usually respond better than adults, } \\
\text { close to healthy children }{ }^{22} \text {, but often } \\
\text { develop vaccine-related fever and } \\
\text { local reactions }{ }^{28} \text {. }\end{array}$ \\
\hline $\begin{array}{l}\text { 23-valent polysaccharide } \\
\text { pneumococcal vaccine } \\
\text { (PPSV23) (L) }\end{array}$ & $\begin{array}{l}\text { At } 12 \text { months: If no chronic GVHD requiring } \\
\text { immunosuppressors: } 1 \text { dose of PPSV23, not } \\
\text { earlier than } 8 \text { weeks after the last PCV (B I). }\end{array}$ & $\begin{array}{l}\text { One dose of PPSV23 at } 12 \text { months after } \\
\text { transplantation and not earlier than } 8 \\
\text { weeks after the last PCV (B I). }\end{array}$ & $\begin{array}{l}\text { The same schedule is recommended } \\
\text { for children and adults. }\end{array}$ \\
\hline N. meningitidis vaccines $(\mathrm{L})$ & $\begin{array}{l}\text { From } 6 \text { months after transplantation: at least } \\
2 \text { doses of either a mono- or tetravalent C } \\
\text { vaccine (B II u) and meningococcal B vaccine }\end{array}$ & $\begin{array}{l}\text { Same recommendation and grading as } \\
\text { for allogeneic HSCT. }\end{array}$ & $\begin{array}{l}\text { The same schedule is recommended } \\
\text { for children and for adults. Children } \\
\text { and adolescents are the main at-risk }\end{array}$ \\
\hline
\end{tabular}




\begin{tabular}{|c|c|c|c|}
\hline & $\begin{array}{l}\text { (B III), in accordance with country } \\
\text { recommendations for a given age and } \\
\text { particularly for risk groups such as students } \\
\text { living in campus, travellers, or soldiers }\end{array}$ & & population. \\
\hline $\begin{array}{l}\text { Tetanus-Diphtheria } \\
\text { vaccine }(\mathrm{L})\end{array}$ & $\begin{array}{l}\text { From } 6 \text { months: } 3 \text { doses at 1-2-month } \\
\text { interval (B II u). } \\
\text { DT vaccines should be preferred over Td } \\
\text { vaccines both in children and adults (C III) } \\
\text { Booster doses to be administered according } \\
\text { to country recommendations. }\end{array}$ & $\begin{array}{l}\text { Same recommendation and grading as } \\
\text { for allogeneic HSCT. }\end{array}$ & $\begin{array}{l}\text { The same schedule is recommended } \\
\text { for children and for adults. Children } \\
\text { usually respond better than adults. }\end{array}$ \\
\hline $\begin{array}{l}\text { Acellular pertussis vaccine } \\
\text { (L) }\end{array}$ & $\begin{array}{l}\text { The addition of pertussis toxoid to the } \\
\text { Diphtheria-Tetanus vaccine, } 3 \text { doses at 1-2- } \\
\text { month interval, should be considered (C III). } \\
\text { Although there is no specific study with DTaP } \\
\text { in adult HSCT recipients, considering the } \\
\text { poor response to Tdap, the DTaP that } \\
\text { contains a higher dose of pertussis toxoid } \\
\text { than the Tdap should be preferred both in } \\
\text { children and adults (C III). }\end{array}$ & $\begin{array}{l}\text { Same recommendation and grading as } \\
\text { for allogeneic HSCT. }\end{array}$ & $\begin{array}{l}\text { The same schedule is recommended } \\
\text { for children and for adults. } \\
\text { Previously unvaccinated HSCT infants } \\
\text { should be vaccinated as soon as } \\
\text { possible. Children seem to respond } \\
\text { better than adults. }\end{array}$ \\
\hline $\begin{array}{l}\text { Inactivated influenza } \\
\text { vaccine (IIV) (C*) }\end{array}$ & $\begin{array}{l}\text { From } 6 \text { months: annual seasonal IIV, } 1 \\
\text { dose, at the beginning of flu season during } \\
\text { the first years following transplant, at least } \\
\text { until } 6 \text { months after stopping any } \\
\text { immunosuppressor and as long as the } \\
\text { patient is judged to be } \\
\text { immunocompromised (A II r) or life-long (B II } \\
\text { r). } \\
\text { A second dose given 3-4 weeks after the first } \\
\text { one may be considered in patients with }\end{array}$ & $\begin{array}{l}\text { From } 6 \text { months: annual seasonal IIV, } 1 \\
\text { dose, at the beginning of flu season, } \\
\text { at least as long as the patient } \\
\text { is judged to be immunocompromised } \\
\text { (B II r). } \\
\text { In the setting of a community } \\
\text { outbreak, IIV can be given from } \\
3 \text { months after transplant. In that case, } \\
\text { a second dose given } 3-4 \text { weeks }\end{array}$ & $\begin{array}{l}\text { Children aged } 6 \text { months to } 8 \text { years, } \\
\text { receiving IIV for the first time after } \\
\text { transplantation should receive a } \\
\text { second dose at least } 4 \text { weeks after } \\
\text { the first dose (B II t). } \\
\text { For children older than } 9 \text { years, a } 2^{\text {nd }} \\
\text { dose of vaccine after } 3-4 \text { weeks may } \\
\text { be considered in patients with severe } \\
\text { GVHD or low lymphocyte counts (B II }\end{array}$ \\
\hline
\end{tabular}




\begin{tabular}{|c|c|c|c|}
\hline & $\begin{array}{l}\text { severe GVHD or low lymphocyte counts (B II } \\
\text { r). } \\
\text { In the setting of a community outbreak, IIV } \\
\text { can be given from } 3 \text { months after } \\
\text { transplantation. In that case, a second dose } \\
\text { given 3-4 weeks later is likely to } \\
\text { be beneficial (B II r). }\end{array}$ & later is likely to be beneficial (B II r). & r). \\
\hline $\begin{array}{l}\text { Inactivated poliomyelitis } \\
\text { vaccine (IPV) (L) }\end{array}$ & $\begin{array}{l}\text { From } 6 \text { to } 12 \text { months: } 3 \text { doses of IPV given at } \\
\text { 1-2-month interval (B II u). } \\
\text { Booster doses should be administered } \\
\text { according to country recommendations. }\end{array}$ & $\begin{array}{l}\text { Same recommendation and grading as } \\
\text { for allogeneic HSCT. }\end{array}$ & $\begin{array}{l}\text { The same schedule is recommended } \\
\text { for children and for adults. Children } \\
\text { usually respond better than adults. } \\
\text { However, owing to a higher risk for } \\
\text { losing polio immunity in the years } \\
\text { after initial vaccination for patients } \\
\text { transplanted before the age of } 10 \\
\text { years, we recommend a regular } \\
\text { assessment of anti-polio Ab titres to } \\
\text { assess persistent immunity and } \\
\text { consider boosters. }\end{array}$ \\
\hline $\begin{array}{l}\text { Hepatitis B virus (HBV) } \\
\text { vaccine }(\mathrm{L})\end{array}$ & $\begin{array}{l}\text { Before transplant: HBV-negative patients for } \\
\text { all markers transplanted with a graft from an } \\
\text { anti-HBc positive donor should be vaccinated } \\
\text { before transplantation if possible (B III) and } \\
\text { may additionally receive anti-HBV } \\
\text { immunoglobulins. } \\
\text { After transplant, from } 6 \text { months: } \\
\text { a) Patients who were negative for HBV } \\
\text { before transplantation and patients who } \\
\text { were vaccinated before transplant but lost } \\
\text { their immunity at } 6 \text { months should be }\end{array}$ & $\begin{array}{l}\text { After transplant, from } 6 \text { months: } \\
\text { a) Patients who were negative for HBV } \\
\text { before transplantation and patients } \\
\text { who were vaccinated before transplant } \\
\text { but lost their immunity at } 6 \text { months } \\
\text { should be vaccinated according to } \\
\text { country recommendation and age ( } 3 \\
\text { doses: } 0,1,6 \text { mo, from } 6-12 \text { mo) } \\
\text { (B II t). } \\
\text { b) Patients infected with HBV before } \\
\text { HSCT (HBsAg- and anti-HBC }+ \text { ) should }\end{array}$ & $\begin{array}{l}\text { The same schedule is proposed for } \\
\text { children and for adults, except that } \\
\text { children should receive a standard } \\
\text { paediatric dose ( } 10 \mu \mathrm{g}) \text { of vaccine } \\
\text { while adolescents should receive } 20 \\
\mu g \text { of the vaccine according to the } \\
\text { summary of product characteristics } \\
\text { of each vaccine. }\end{array}$ \\
\hline
\end{tabular}




\begin{tabular}{|c|c|c|c|}
\hline & $\begin{array}{l}\text { vaccinated according to country } \\
\text { recommendation ( } 3 \text { doses: 0, 1, } 6 \text { mo, from } \\
6-12 \text { mo) } \\
\text { (B II t). } \\
\text { b) Patients infected with HBV before HSCT } \\
\text { (HBsAg- and anti-HBc+) should be assessed } \\
\text { regularly for anti-HBs Ab titres and be } \\
\text { vaccinated if they have unprotective titres (B } \\
\text { III). } \\
\text { If anti-HBs titres are <10 mIU/mL 1-2 months } \\
\text { after the initial series of } 3 \text { vaccine doses, an } \\
\text { additional series of } 3 \text { doses should be } \\
\text { considered. }\end{array}$ & $\begin{array}{l}\text { have anti-HBs Ab titres assessed } \\
\text { regularly and be vaccinated if they } \\
\text { have unprotective titres (B III). } \\
\text { If anti-HBs titres are }<10 \mathrm{mIU} / \mathrm{mL} 1-2 \\
\text { months after the initial series of } 3 \\
\text { vaccine doses, an additional series of } 3 \\
\text { doses should be considered. }\end{array}$ & \\
\hline $\begin{array}{l}\text { Human papillomavirus } \\
\text { (HPV) vaccine (L) }\end{array}$ & $\begin{array}{l}\text { From 6-12 months: follow recommendations } \\
\text { for general population in each country (BIlu) }\end{array}$ & $\begin{array}{l}\text { Same recommendation and grading as } \\
\text { for allogeneic HSCT. }\end{array}$ & $\begin{array}{l}\text { Follow age recommendations for } \\
\text { general population in each country }\end{array}$ \\
\hline
\end{tabular}

*L: Guideline proposed on the basis of clinical endpoints. C: Guideline proposed on the basis of laboratory endpoints. 
Table 3 : ECIL 7 recommendations for vaccination of HSCT recipients with live-attenuated vaccines (LAV)

\begin{tabular}{|c|c|c|c|}
\hline Vaccine & $\begin{array}{c}\text { Recommendation and grading for } \\
\text { allogeneic HSCT }\end{array}$ & $\begin{array}{c}\text { Recommendation and grading for } \\
\text { autologous HSCT }\end{array}$ & Paediatric specificities \\
\hline \multicolumn{4}{|c|}{ All LAV are contraindicated as long as the patient is considered severely immunocompromised. } \\
\hline $\begin{array}{l}\text { Varicella LAV (LAVV) } \\
\left(\mathrm{C}^{*}\right)\end{array}$ & $\begin{array}{l}\text { LAVV is contraindicated in HSCT recipients } \\
\text { with active GVHD, relapse of the } \\
\text { underlying disease, or ongoing } \\
\text { immunosuppression (D III). } \\
\text { From at least } 24 \text { months: One dose of } \\
\text { LAVV can be considered in VZV } \\
\text { seronegative adult patients with no } \\
\text { GVHD, no ongoing immunosuppression, } \\
\text { no relapse of the underlying disease, and } \\
\text { no treatment with immunoglobulins } \\
\text { during the previous months** (B II r). } \\
\text { The addition of a } 2^{\text {nd }} \text { dose in adults may } \\
\text { be considered in patients who were } \\
\text { seronegative before HSCT or had no } \\
\text { history of VZV infection. }\end{array}$ & $\begin{array}{l}\text { Same recommendation as after allogeneic } \\
\text { HSCT. }\end{array}$ & $\begin{array}{l}\text { Two doses (instead of } 1 \text { dose in } \\
\text { adults) of LAVV can be considered in } \\
\text { children meeting the same limitation } \\
\text { criteria than in adults (B II r). The } \\
\text { interval between } 2 \text { doses should be } \\
\text { the one recommended in the official } \\
\text { label. }\end{array}$ \\
\hline Zoster LAV & Not recommended (DIII) & Not recommended (DIII) & Not recommended (DIII) \\
\hline $\begin{array}{l}\text { Measles-mumps-rubella } \\
(\mathrm{MMR})\left(\mathrm{L}^{*}\right)\end{array}$ & $\begin{array}{l}\text { From } 24 \text { months: HSCT recipients should } \\
\text { have MMR Ab titres tested (B II u) } \\
\text { Consider vaccination only in patients with } \\
\text { no GVHD, no immunosuppression, no }\end{array}$ & $\begin{array}{l}\text { Same recommendation as after allogeneic } \\
\text { HSCT. }\end{array}$ & $\begin{array}{l}\text { Owing to a lower response in } \\
\text { children, } 2 \text { doses - instead of one in } \\
\text { adults - should be considered in } \\
\text { children, at least } 4 \text { weeks apart. }\end{array}$ \\
\hline
\end{tabular}




\begin{tabular}{|c|c|c|c|}
\hline & $\begin{array}{l}\text { relapse of the underlying disease, and } \\
\text { treatment with immunoglobulins during } \\
\text { the previous months**. } \\
\text { Seronegative patients for measles should } \\
\text { receive } 1 \text { dose of MMR (B II u). } \\
\text { HSCT recipient women who are } \\
\text { seronegative for rubella and of } \\
\text { childbearing potential should receive } 1 \\
\text { dose of MMR with the same precautions } \\
\text { (C II u). } \\
\text { In case of measles outbreak, MMR } \\
\text { vaccination could be considered from } 12 \\
\text { months after transplantation in patients } \\
\text { with low-grade immunosuppression (C III) }\end{array}$ & & \\
\hline Yellow fever (L) & $\begin{array}{l}\text { YF vaccine should be considered } \\
\text { cautiously only in patients with no active } \\
\text { GvHD, no immunosuppressive drugs, and } \\
\text { if travel to endemic area cannot be } \\
\text { avoided, before } 24 \text { months (DIII) or from } \\
24 \text { months (CIII). }\end{array}$ & $\begin{array}{l}\text { YF vaccine should be considered cautiously, } \\
\text { if travel to endemic area cannot be } \\
\text { avoided, before } 24 \text { months (DIII) or from } \\
24 \text { months (CIII). }\end{array}$ & $\begin{array}{l}\text { Although there are no data in } \\
\text { children, the same schedule is } \\
\text { recommended for children and for } \\
\text { adults. }\end{array}$ \\
\hline
\end{tabular}

** L: Guideline proposed on the basis of clinical endpoints. C: Guideline proposed on the basis of laboratory endpoints.

**The interval between the last immunoglobulin administration and the administration of a varicella or MMR live-attenuated vaccine should be at least 3 months, ideally between 8 and 11 months. 
Table 4 : Main data on donor immunisation before allogeneic HSCT donation.

\begin{tabular}{|c|c|c|}
\hline Vaccine & Benefit of donor immunisation before donation on the post-transplant vaccine response of the recipient & References \\
\hline PCV & Improved after early vaccination, no more significant at 12 months & 29,30 \\
\hline PPSV23 & No benefit & 29,141 \\
\hline H influenzae B & Improves the response of early $(\mathrm{d}-1, \mathrm{~d} 50)$ vaccination & 141 \\
\hline$N$ meningitidis & Unknown & \\
\hline Tetanus-Diphtheria & $\begin{array}{l}\text { Tetanus: Improves the response of early }(\mathrm{d}-1, \mathrm{~d} 50) \text { vaccination } \\
\text { Diphtheria: Increases antibodies concentrations. }\end{array}$ & 42,141 \\
\hline Acellular pertussis & Unknown & \\
\hline Poliomyelitis & No benefit & 42 \\
\hline Inactivated influenza & $\begin{array}{l}\text { No difference in antibody levels after vaccination during the first } 6 \text { months after transplant } \\
\text { No improved response when vaccinated at } 6 \text { months }\end{array}$ & 74 \\
\hline Hepatitis B virus & Poor response to HBsAg with or without donor vaccination in Storek et al. & 141,142 \\
\hline
\end{tabular}


Improved response to KLH (keyhole limpet hemocyanin) in Wimperis et al.

Human papillomavirus

Unknown 
Table 5: ECIL 7 recommendations for family and close contacts of stem cell transplant recipients.

\begin{tabular}{|c|c|c|}
\hline Vaccine & Recommendation & Grading \\
\hline General recommendation & $\begin{array}{l}\text { It is recommended that the family members and close contacts of HSCT recipients be immunised or } \\
\text { vaccinated according to the age and country recommendation, }\end{array}$ & \\
\hline Influenza inactivated vaccine (IIV) & $\begin{array}{l}\text { It is recommended that family members and close contacts of HSCT recipients be vaccinated with IIV } \\
\text { beginning the season before and first season after transplantation and annually as long as the patient is } \\
\text { considered immunocompromised. }\end{array}$ & $\begin{array}{l}\text { Allt } \\
\text { CIII }\end{array}$ \\
\hline \multicolumn{3}{|c|}{ Contraindications or specific precautions } \\
\hline Live-attenuated influenza vaccine & $\begin{array}{l}\text { The nasal LAV influenza vaccine is contra-indicated in the close contacts of HSCT recipients during the first } \\
\text { months of transplant or if the patient has GVHD. }\end{array}$ & BIII \\
\hline $\begin{array}{l}\text { Varicella or measles-mumps-rubella } \\
\text { vaccine to a close contact of the } \\
\text { patient }\end{array}$ & $\begin{array}{l}\text { In case a close contact of an HSCT recipient needs LAV for varicella because he/she is seronegative, he/she } \\
\text { should be separated from the patient in case of post-vaccine disease. }\end{array}$ & \\
\hline Rotavirus vaccine in close infants & Within 4 weeks following rotavirus vaccination of infants, HSCT recipients should have no contact with the & \\
\hline
\end{tabular}




\section{REFERENCES}

1. Giebink GS, Warkentin PI, Ramsay NK, Kersey JH. Titers of antibody to pneumococci in allogeneic bone marrow transplant recipients before and after vaccination with pneumococcal vaccine. J Infect Dis 1986;154(4):590-6.

2. Sheridan JF, Tutschka PJ, Sedmak DD, Copelan EA. Immunoglobulin G subclass deficiency and pneumococcal infection after allogeneic bone marrow transplantation. Blood 1990;75(7):1583-6. 3. Winston DJ, Ho WG, Schiffman G, Champlin RE, Feig SA, Gale RP. Pneumococcal vaccination of recipients of bone marrow transplants. Arch Intern Med 1983;143(9):1735-7.

4. Winston DJ, Schiffman G, Wang DC, et al. Pneumococcal infections after human bone-marrow transplantation. Ann Intern Med 1979;91(6):835-41.

5. Meerveld-Eggink A, van der Velden AM, Ossenkoppele GJ, van de Loosdrecht AA, Biesma DH, Rijkers GT. Antibody response to polysaccharide conjugate vaccines after nonmyeloablative allogeneic stem cell transplantation. Biol Blood Marrow Transplant 2009;15(12):1523-30.

6. Pao M, Papadopoulos EB, Chou J, et al. Response to pneumococcal (PNCRM7) and haemophilus influenzae conjugate vaccines (HIB) in pediatric and adult recipients of an allogeneic hematopoietic cell transplantation (alloHCT). Biol Blood Marrow Transplant 2008;14(9):1022-30.

7. Ljungman P, Fridell E, Lönnqvist B, al. e. Efficacy and safety of vaccination of marrow transplant recipients with a live attenuated measles, mumps, and rubella vaccine. J Infect Dis 1989;159:610-15. 8. Ljungman P, Lewensohn-Fuchs I, Hammarstrom V, et al. Long-term immunity to measles, mumps, and rubella after allogeneic bone marrow transplantation. Blood 1994;84(2):657-63.

9. Machado C, Goncalves F, Pannuti C, al. e. Measles in bone marrow transplant recipients during an outbreak in Sao Paulo, Brazil. Blood 2002;99:83-87.

10. Pauksen K, Duraj V, Ljungman P, et al. Immunity to and immunization against measles, rubella and mumps in patients after autologous bone marrow transplantation. Bone Marrow Transplant 1992;9:427-432. 
11. Wahren B, Gahrton G, Linde A, et al. Transfer and persistence of viral antibody-producing cells in bone marrow transplantation. J Infect Dis 1984;150(3):358-65.

12. Cesaro S, Giacchino M, Fioredda F, et al. Guidelines on vaccinations in paediatric haematology and oncology patients. Biomed Res Int 2014;2014:707691.

13. Ljungman P. Vaccination of immunocompromised patients. Clin Microbiol Infect 2012;18 Suppl 5:93-9.

14. Ljungman $\mathrm{P}$, Cordonnier $\mathrm{C}$, Einsele $\mathrm{H}$, et al. Vaccination of hematopoietic cell transplant recipients. Bone Marrow Transplant 2009;44(8):521-6.

15. Rubin LG, Levin MJ, Ljungman P, et al. 2013 IDSA clinical practice guideline for vaccination of the immunocompromised host. Clin Infect Dis 2014;58(3):309-18.

16. Ljungman P, Engelhard D, De la Camara R, et al. Vaccination of stem cell transplant recipients: recommendations of the Infectious Diseases Working Party of the EBMT. Bone Marrow Transplant 2005;35:737-46.

17. Mikulska M, Cesaro S, de La Vallade H, et al. Vaccination of non -transplanted patients with haematological malignancies: Guidelines from the 7th European Conference on Infections in Leukaemia. . Submitted companion paper. 2018.

18. Cuenca-Estrella M, Verweij PE, Arendrup MC, et al. ESCMID* guideline for the diagnosis and management of Candida diseases 2012: diagnostic procedures. Clin Microbiol Infect 2012;18 Suppl 7:9-18.

19. Engelhard D, Cordonnier C, Shaw PJ, et al. Early and late invasive pneumococcal infection following stem cell transplantation: a European Bone Marrow Transplantation survey. Br J Haematol 2002;117(2):444-50.

20. Youssef S, Rodriguez G, Rolston KV, Champlin RE, Raad, II, Safdar A. Streptococcus pneumoniae infections in $\mathbf{4 7}$ hematopoietic stem cell transplantation recipients: clinical characteristics of infections and vaccine-breakthrough infections, 1989-2005. Medicine (Baltimore) 2007;86(2):69-77. 
21. Cordonnier C, Labopin M, Chesnel V, et al. Randomized study of early versus late immunization with pneumococcal conjugate vaccine after allogeneic stem cell transplantation. Clin Infect Dis 2009;48(10):1392-401.

22. Meisel R, Kuypers L, Dirksen U, et al. Pneumococcal conjugate vaccine provides early protective antibody responses in children after related and unrelated allogeneic hematopoietic stem cell transplantation. Blood 2007;109(6):2322-6.

23. Debbache K, Varon E, Hicheri Y, et al. The epidemiology of invasive Streptococcus pneumoniae infections in onco-haematology and haematopoietic stem cell transplant patients in France. Are the serotypes covered by the available anti-pneumococcal vaccines? Clin Microbiol Infect 2009;15(9):865-8.

24. Olarte L, Lin PL, Barson WJ, et al. Invasive pneumococcal infections in children following transplantation in the pneumococcal conjugate vaccine era. Transpl Infect Dis 2017;19(1). 25. Parkkali T, Kayhty H, Ruutu T, Volin L, Eskola J, Ruutu P. A comparison of early and late vaccination with Haemophilus influenzae type $b$ conjugate and pneumococcal polysaccharide vaccines after allogeneic BMT. Bone Marrow Transplant 1996;18(5):961-7.

26. Avanzini MA, Carra AM, Maccario R, et al. Antibody response to pneumococcal vaccine in children receiving bone marrow transplantation. J Clin Immunol 1995;15(3):137-44.

27. Cordonnier C, Labopin M, Chesnel V, et al. Immune response to the 23-valent polysaccharide vaccine after the 7-valent conjugate vaccine in allogeneic stem cell transplant recipients: Results from the EBMT IDWP01 trial. Vaccine 2010;28(15):2730-4.

28. Cordonnier C, Ljungman P, Juergens $C$, et al. Immunogenicity, Safety, and Tolerability of 13-Valent Pneumococcal Conjugate Vaccine Followed by 23-Valent Pneumococcal Polysaccharide Vaccine in Recipients of Allogeneic Hematopoietic Stem Cell Transplant Aged 2 Years and Older: An Open-Label Study. Clin Infect Dis 2015.

29. Kumar D, Chen MH, Welsh B, et al. A randomized, double-blind trial of pneumococcal vaccination in adult allogeneic stem cell transplant donors and recipients. Clin Infect Dis 2007;45(12):1576-82. 
30. Molrine DC, Antin JH, Guinan EC, et al. Donor immunization with pneumococcal conjugate vaccine and early protective antibody responses following allogeneic hematopoietic cell transplantation. Blood 2003;101(3):831-6.

31. Cordonnier C, Labopin M, Jansen KU, et al. Relationship between IgG titers and opsonocytophagocytic activity of anti-pneumococcal antibodies after immunization with the 7-valent conjugate vaccine in allogeneic stem cell transplant. Bone Marrow Transplant 2010;45(9):1423-6.

32. Cordonnier C, Labopin M, Robin C, et al. Long-term persistence of the immune response to antipneumococcal vaccines after Allo-SCT: 10-year follow-up of the EBMT-IDWP01 trial. Bone Marrow Transplant 2015.

33. Olkinuora H, Kayhty H, Davidkin I, et al. Immunity after (re)vaccination of paediatric patients following haematopoietic stem cell transplantation. Acta Paediatr 2012;101(8):e373-7. 34. Shah GL, Shune L, Purtill D, et al. Robust Vaccine Responses in Adult and Pediatric Cord Blood Transplantation Recipients Treated for Hematologic Malignancies. Biol Blood Marrow Transplant 2015;21(12):2160-6.

35. Gandhi MK, Egner W, Sizer L, et al. Antibody responses to vaccinations given within the first two years after transplant are similar between autologous peripheral blood stem cell and bone marrow transplant recipients. Bone Marrow Transplant 2001;28(8):775-81.

36. Antin JH, Guinan EC, Avigan D, et al. Protective antibody responses to pneumococcal conjugate vaccine after autologous hematopoietic stem cell transplantation. Biol Blood Marrow Transplant 2005;11(3):213-22.

37. Atkinson K, Storb R, Prentice RL, et al. Analysis of late infections in 89 long-term survivors of bone marrow transplantation. Blood 1979;53(4):720-31.

38. Cordonnier C, Bernaudin JF, Bierling P, Huet Y, Vernant JP. Pulmonary complications occurring after allogeneic bone marrow transplantation. A study of 130 consecutive transplanted patients. Cancer 1986;58(5):1047-54. 
39. Aucouturier P, Barra A, Intrator L, et al. Long lasting IgG subclass and antibacterial polysaccharide antibody deficiency after allogeneic bone marrow transplantation. Blood 1987;70(3):779-85.

40. Barra A, Cordonnier C, Preziosi MP, et al. Immunogenicity of Haemophilus influenzae type b conjugate vaccine in allogeneic bone marrow recipients. J Infect Dis 1992;166(5):1021-8.

41. Molrine DC, Guinan EC, Antin JH, et al. Haemophilus influenzae type b (HIB)-conjugate immunization before bone marrow harvest in autologous bone marrow transplantation. Bone Marrow Transplant 1996;17(6):1149-55.

42. Parkkali T, Kayhty H, Hovi T, et al. A randomized study on donor immunization with tetanusdiphtheria, Haemophilus influenzae type $b$ and inactivated poliovirus vaccines to improve the recipient responses to the same vaccines after allogeneic bone marrow transplantation. Bone Marrow Transplant 2007;39(3):179-88.

43. van der Velden AM, Claessen AM, van Velzen-Blad H, et al. Vaccination responses and lymphocyte subsets after autologous stem cell transplantation. Vaccine 2007;25(51):8512-7. 44. Vance E, George S, Guinan EC, et al. Comparison of multiple immunization schedules for Haemophilus influenzae type b-conjugate and tetanus toxoid vaccines following bone marrow transplantation. Bone Marrow Transplant 1998;22(8):735-41.

45. Guinan EC, Molrine DC, Antin JH, et al. Polysaccharide conjugate vaccine responses in bone marrow transplant patients. Transplantation 1994;57(5):677-84.

46. Molrine DC, Guinan EC, Antin JH, et al. Donor immunization with Haemophilus influenzae type b (HIB)-conjugate vaccine in allogeneic bone marrow transplantation. Blood 1996;87(7):3012-8.

47. Parkkali T, Kayhty H, Anttila M, et al. IgG subclasses and avidity of antibodies to polysaccharide antigens in allogeneic BMT recipients after vaccination with pneumococcal polysaccharide and Haemophilus influenzae type b conjugate vaccines. Bone Marrow Transplant 1999;24(6):671-8. 48. Chan CY, Molrine DC, Antin JH, et al. Antibody responses to tetanus toxoid and Haemophilus influenzae type b conjugate vaccines following autologous peripheral blood stem cell transplantation (PBSCT). Bone Marrow Transplant 1997;20(1):33-8. 
49. Whittaker R, Economopoulou A, Dias JG, Bancroft E, Ramliden M, Celentano LP. Epidemiology of Invasive Haemophilus influenzae Disease, Europe, 2007-2014. Emerg Infect Dis 2017;23(3):396-404. 50. van Veen KE, Brouwer MC, van der Ende A, van de Beek D. Bacterial meningitis in hematopoietic stem cell transplant recipients: a population-based prospective study. Bone Marrow Transplant 2016;51(11):1490-1495.

51. Parkkali T, Kayhty $\mathrm{H}$, Lehtonen $\mathrm{H}$, et al. Tetravalent meningococcal polysaccharide vaccine is immunogenic in adult allogeneic BMT recipients. Bone Marrow Transplant 2001;27(1):79-84.

52. Patel SR, Ortin M, Cohen BJ, et al. Revaccination with measles, tetanus, poliovirus, Haemophilus influenzae type $B$, meningococcus $C$, and pneumococcus vaccines in children after hematopoietic stem cell transplantation. Clin Infect Dis 2007;44(5):625-34.

53. Mahler MB, Taur Y, Jean R, Kernan NA, Prockop SE, Small TN. Safety and immunogenicity of the tetravalent protein-conjugated meningococcal vaccine (MCV4) in recipients of related and unrelated allogeneic hematopoietic stem cell transplantation. Biol Blood Marrow Transplant 2012;18(1):145-9. 54. Feavers IM, Maiden MC. Recent progress in the prevention of serogroup B meningococcal disease. Clin Vaccine Immunol 2017.

55. Whittaker R, Dias JG, Ramliden M, et al. The epidemiology of invasive meningococcal disease in EU/EEA countries, 2004-2014. Vaccine 2017;35(16):2034-2041.

56. Ljungman $\mathrm{P}$, Wiklund-Hammarsten $\mathrm{M}$, Duraj $\mathrm{V}$, et al. Response to tetanus toxoid immunization after allogeneic bone marrow transplantation. J Infect Dis 1990;162(2):496-500.

57. Inaba $\mathrm{H}$, Hartford $\mathrm{CM}$, Pei $\mathrm{D}$, et al. Longitudinal analysis of antibody response to immunization in paediatric survivors after allogeneic haematopoietic stem cell transplantation. Br J Haematol 2012;156(1):109-17.

58. Parkkali T, Olander RM, Ruutu T, et al. A randomized comparison between early and late vaccination with tetanus toxoid vaccine after allogeneic BMT. Bone Marrow Transplant 1997;19(9):933-8. 
59. Nordoy T, Husebekk A, Aaaberge I, et al. Humoral immunity to viral and bacterial antigens in lymphoma patients $4-10$ years after high-dose therapy with ABMT. Serological responses to revaccinations according to EBMT guidelines. Bone Marrow Transplant 2001;28:681-7. 60. Small TN, Zelenetz AD, Noy A, et al. Pertussis immunity and response to tetanus-reduced diphtheria-reduced pertussis vaccine (Tdap) after autologous peripheral blood stem cell transplantation. Biol Blood Marrow Transplant 2009;15(12):1538-42.

61. Heininger U, Andre $P$, Chlibek R, et al. Comparative Epidemiologic Characteristics of Pertussis in 10 Central and Eastern European Countries, 2000-2013. PLoS One 2016;11(6):e0155949.

62. Florax A, Ehlert K, Becker K, Vormoor J, Groll AH. Bordetella pertussis respiratory infection following hematopoietic stem cell transplantation: time for universal vaccination? Bone Marrow Transplant 2006;38(9):639-40.

63. Kochethu G, Clark FJ, Craddock CF. Pertussis: should we vaccinate post transplant? Bone Marrow Transplant 2006;37(8):793-4.

64. Suzuki N, Mizue N, Hori T, Hatakeyama N, Kudoh T, Tsutsumi H. Pertussis in adolescence after unrelated cord blood transplantation. Bone Marrow Transplant 2003;32(9):967.

65. Yacoub A, Nanjappa S, Janz T, Greene JN. Infectious Disease Report: Bordetella pertussis Infection in Patients With Cancer. Cancer Control 2016;23(2):163-6.

66. Papadopoulos E, Young J, Kernan N, et al. Use of the Tetanus Toxoid, Reduced Dose Diphtheria and Pertussis Vaccine (Tdap) in Allogeneic Transplant (alloHCT) Recipients. Blood 2008;112:2214. 67. Choi SM, Boudreault AA, Xie H, Englund JA, Corey L, Boeckh M. Differences in clinical outcomes after 2009 influenza A/H1N1 and seasonal influenza among hematopoietic cell transplant recipients. Blood 2011;117(19):5050-6.

68. Ljungman $P$, de la Camara R, Perez-Bercoff $L$, et al. Outcome of pandemic H1N1 infections in hematopoietic stem cell transplant recipients. Haematologica 2011;96(8):1231-5. 
69. Nichols WG, Guthrie KA, Corey L, Boeckh M. Influenza infections after hematopoietic stem cell transplantation: risk factors, mortality, and the effect of antiviral therapy. Clin Infect Dis 2004;39(9):1300-6.

70. Machado CM, Cardoso MR, da Rocha IF, Boas LS, Dulley FL, Pannuti CS. The benefit of influenza vaccination after bone marrow transplantation. Bone Marrow Transplant 2005;36(10):897-900.

71. Ambati A, Einarsdottir S, Magalhaes I, et al. Immunogenicity of virosomal adjuvanted trivalent influenza vaccination in allogeneic stem cell transplant recipients. Transpl Infect Dis 2015;17(3):3719.

72. Engelhard D, Nagler A, Hardan I, et al. Antibody response to a two-dose regimen of influenza vaccine in allogeneic T cell-depleted and autologous BMT recipients. Bone Marrow Transplant $1993 ; 11(1): 1-5$

73. Natori Y, Humar A, Lipton J, et al. A pilot randomized trial of adjuvanted influenza vaccine in adult allogeneic hematopoietic stem cell transplant recipients. Bone Marrow Transplant 2017.

74. Ambati A, Boas LS, Ljungman $P$, et al. Evaluation of pretransplant influenza vaccination in hematopoietic SCT: a randomized prospective study. Bone Marrow Transplant 2015;50(6):858-64. 75. Karras NA, Weeres $M$, Sessions $W$, et al. A randomized trial of one versus two doses of influenza vaccine after allogeneic transplantation. Biol Blood Marrow Transplant 2013;19(1):109-16.

76. Pauksen K, Linde A, Hammarstrom V, et al. Granulocyte-Macrophage Colony-Stimulating Factor as Immunomodulating Factor Together with Influenza Vaccination in Stem Cell Transplant Patients. Clin Infect Dis 2000;30:342-8.

77. Dhédin N, Krivine A, Le Corre N, et al. Comparable humoral response after two doses of adjuvanted influenza A/H1N1pdm2009 vaccine or natural infection in allogeneic stem cell transplant recipients. Vaccine 2014;32:585-91.

78. Engelhard D, Zakay-Rones Z, Shapira M, et al. The humoral immune response of hematopoietic stem cell transplantation recipients to AS03-adjuvanted A/California/7/2009 (H1N1)v-like virus vaccine during the 2009 pandemic. Vaccine 2011;29(9):1777-82. 
79. Mohty B, Bel M, Vukicevic M, et al. Graft-versus-host disease is the major determinant of humoral responses to the AS03-adjuvanted influenza A/09/H1N1 vaccine in allogeneic hematopoietic stem cell transplant recipients. Haematologica 2011;96(6):896-904.

80. Issa NC, Marty FM, Gagne LS, et al. Seroprotective titers against 2009 H1N1 influenza A virus after vaccination in allogeneic hematopoietic stem cell transplantation recipients. Biol Blood Marrow Transplant 2011;17(3):434-8.

81. Fukatsu Y, Nagata Y, Adachi M, Yagyu T, Ono T. Serum IgM levels independently predict immune response to influenza vaccine in long-term survivors vaccinated at $>1$ year after undergoing allogeneic hematopoietic stem cell transplantation. Int J Hematol 2016.

82. de Lavallade H, Garland P, Sekine T, et al. Repeated vaccination is required to optimize seroprotection against H1N1 in the immunocompromised host. Haematologica 2011;96(2):307-14. 83. Halasa NB, Savani BN, Asokan I, et al. Randomized Double-Blind Study of the Safety and Immunogenicity of Standard-Dose Trivalent Inactivated Influenza Vaccine versus High-Dose Trivalent Inactivated Influenza Vaccine in Adult Hematopoietic Stem Cell Transplantation Patients. Biol Blood Marrow Transplant 2016;22(3):528-35.

84. Engelhard D, Mohty B, De La Camara R, Cordonnier C, Ljungman P. European guidelines for prevention and management of influenza in hematopoietic stem cell transplantation and leukemia patients: summary of ECIL-4 (2011), on behalf of ECIL, a joint venture of EBMT, EORTC, ICHS, and ELN. Transplant Infect Dis 2013;15(3):219-32.

85. Engelhard D, Handsher R, Naparstek E, et al. Immune response to polio vaccination in bone marrow transplant recipients. Bone Marrow Transplant 1991;8(4):295-300.

86. Ljungman P, Duraj V, Magnius L. Response to immunization against polio after allogeneic marrow transplantation. Bone Marrow Transplant 1991;7(2):89-93.

87. Parkkali T, Ruutu T, Stenvik M, et al. Loss of protective immunity to polio, diphtheria and Haemophilus influenzae type $b$ after allogeneic bone marrow transplantation. Apmis 1996;104(5):383-8. 
88. Parkkali T, Stenvik M, Ruutu T, Hovi T, Volin L, Ruutu P. Randomized comparison of early and late vaccination with inactivated poliovirus vaccine after allogeneic BMT. Bone Marrow Transplant 1997;20(8):663-8.

89. Pauksen K, Hammarstrom V, Ljungman $\mathrm{P}$, et al. Immunity to poliovirus and immunization with inactivated poliovirus vaccine after autologous bone marrow transplantation. Clin Infect Dis 1994;18(4):547-52.

90. Ljungman P, Aschan J, Gustafsson B, Lewensohn-Fuchs I, Winiarski J, Ringden O. Long-term immunity to poliovirus after vaccination of allogeneic stem cell transplant recipients. Bone Marrow Transplant 2004;34(12):1067-9.

91. Mallet V, van Bommel F, Doerig C, et al. Management of viral hepatitis in patients with haematological malignancy and in patients undergoing haemopoietic stem cell transplantation: recommendations of the 5th European Conference on Infections in Leukaemia (ECIL-5). Lancet Infect Dis 2016;16(5):606-617.

92. Ilan Y, Nagler A, Adler R, et al. Adoptive transfer of immunity to hepatitis B virus after T celldepleted allogeneic bone marrow transplantation. Hepatology 1993;18(2):246-52.

93. Jaffe D, Papadopoulos EB, Young JW, et al. Immunogenicity of recombinant hepatitis B vaccine (rHBV) in recipients of unrelated or related allogeneic hematopoietic cell $(\mathrm{HC})$ transplants. Blood 2006;108(7):2470-5.

94. Kaloyannidis P, Batsis I, Yannaki E, et al. Allografted recipients immunized against hepatitis B virus are at high risk of gradual surface antibody (HbsAb) disappearance post transplant, regardless of adoptive immunity transfer. Biol Blood Marrow Transplant 2007;13(9):1049-56.

95. Hui CK, Sun J, Au WY, et al. Occult hepatitis B virus infection in hematopoietic stem cell donors in a hepatitis B virus endemic area. J Hepatol 2005;42(6):813-9.

96. Marchou B, Excler JL, Bourderioux C, et al. A 3-week hepatitis B vaccination schedule provides rapid and persistent protective immunity: a multicenter, randomized trial comparing accelerated and classic vaccination schedules. J Infect Dis 1995;172(1):258-60. 
97. Le Q, Shenoy A, Koklanaris E, Childs R, John Barrett A, Savani BN. Lamivudine prophylaxis and hepatitis B vaccination for prevention of hepatitis B virus reverse seroconversion in long-term survivors after allogeneic stem cell transplantation. Biol Blood Marrow Transplant 2009;15(7):886-7. 98. Onozawa $\mathrm{M}$, Hashino S, Darmanin S, et al. HB vaccination in the prevention of viral reactivation in allogeneic hematopoietic stem cell transplantation recipients with previous HBV infection. Biol Blood Marrow Transplant 2008;14(11):1226-30.

99. Bailey HH, Chuang LT, duPont NC, et al. American Society of Clinical Oncology Statement: Human Papillomavirus Vaccination for Cancer Prevention. J Clin Oncol 2016;34(15):1803-12.

100. Savani BN, Stratton P, Shenoy A, Kozanas E, Goodman S, Barrett AJ. Increased risk of cervical dysplasia in long-term survivors of allogeneic stem cell transplantation--implications for screening and HPV vaccination. Biol Blood Marrow Transplant 2008;14(9):1072-5.

101. Maclntyre CR, Shaw P, Mackie FE, et al. Immunogenicity and persistence of immunity of a quadrivalent Human Papillomavirus (HPV) vaccine in immunocompromised children. Vaccine 2016;34(36):4343-50.

102. Kumar D, Unger ER, Panicker G, Medvedev P, Wilson L, Humar A. Immunogenicity of quadrivalent human papillomavirus vaccine in organ transplant recipients. Am J Transplant 2013;13(9):2411-7.

103. Vichnin M, Bonanni P, Klein NP, et al. An Overview of Quadrivalent Human Papillomavirus Vaccine Safety: 2006 to 2015. Pediatr Infect Dis J 2015;34(9):983-91.

104. Avetisyan G, Aschan J, Hassan M, Ljungman P. Evaluation of immune responses to seasonal influenza vaccination in healthy volunteers and in patients after stem cell transplantation. Transplantation 2008;86(2):257-63.

105. Gelinck LB, van den Bemt BJ, Marijt WA, et al. Intradermal influenza vaccination in immunocompromized patients is immunogenic and feasible. Vaccine 2009;27(18):2469-74. 106. Croce E, Hatz C, Jonker EF, Visser LG, Jaeger VK, Buhler S. Safety of live vaccinations on immunosuppressive therapy in patients with immune-mediated inflammatory diseases, solid organ 
transplantation or after bone-marrow transplantation - A systematic review of randomized trials, observational studies and case reports. Vaccine 2017;35(9):1216-1226.

107. Styczynski J, Reusser P, Einsele H, et al. Management of HSV, VZV and EBV infections in patients with hematological malignancies and after SCT: guidelines from the Second European Conference on Infections in Leukemia. Bone Marrow Transplant 2009;43(10):757-70.

108. Bhalla P, Forrest GN, Gershon M, et al. Disseminated, persistent, and fatal infection due to the vaccine strain of varicella-zoster virus in an adult following stem cell transplantation. Clin Infect Dis 2015;60(7):1068-74.

109. Schrauder A, Henke-Gendo C, Seidemann K, et al. Varicella vaccination in a child with acute lymphoblastic leukaemia. Lancet 2007;369(9568):1232.

110. Costa E, Buxton J, Brown J, Templeton KE, Breuer J, Johannessen I. Fatal disseminated varicella zoster infection following zoster vaccination in an immunocompromised patient. BMJ Case Rep 2016;2016.

111. Ljungman P, Wang FZ, Nilsson C, Solheim V, Linde A. Vaccination of autologous stem cell transplant recipients with live varicella vaccine: a pilot study. Support Care Cancer 2003;11(11):73941.

112. Sasadeusz J, Prince HM, Schwarer A, et al. Immunogenicity and safety of a two-dose live attenuated varicella vaccine given to adults following autologous hematopoietic stem cell transplantation. Transpl Infect Dis 2014;16(6):1024-31.

113. Sauerbrei A, Prager J, Hengst U, Zintl F, Wutzler P. Varicella vaccination in children after bone marrow transplantation. Bone Marrow Transplant 1997;20(5):381-3.

114. Kussmaul SC, Horn BN, Dvorak CC, Abramovitz L, Cowan MJ, Weintrub PS. Safety of the live, attenuated varicella vaccine in pediatric recipients of hematopoietic SCTs. Bone Marrow Transplant 2010;45(11):1602-6.

115. Jamani K, MacDonald J, Lavoie M, et al. Zoster prophylaxis after allogeneic hematopoietic cell transplantation using acyclovir/valacyclovir followed by vaccination. Blood Adv 2016;1(2):152-159. 
116. Aoki T, Koh K, Kawano Y, et al. Safety of Live Attenuated High-Titer Varicella-Zoster Virus Vaccine in Pediatric Allogeneic Hematopoietic Stem Cell Transplantation Recipients. Biol Blood Marrow Transplant 2016;22(4):771-5.

117. Issa NC, Marty FM, Leblebjian H, et al. Live attenuated varicella-zoster vaccine in hematopoietic stem cell transplantation recipients. Biol Blood Marrow Transplant 2014;20(2):285-7.

118. Pandit A, Leblebjian H, Hammond SP, et al. Safety of live-attenuated measles-mumps-rubella and herpes zoster vaccination in multiple myeloma patients on maintenance lenalidomide or bortezomib after autologous hematopoietic cell transplantation. Bone Marrow Transplant 2018. 119. Cunningham AL, Lal H, Kovac M, et al. Efficacy of the Herpes Zoster Subunit Vaccine in Adults 70 Years of Age or Older. N Engl J Med 2016;375(11):1019-32.

120. Stadtmauer EA, Sullivan KM, Marty FM, et al. A phase 1/2 study of an adjuvanted varicellazoster virus subunit vaccine in autologous hematopoietic cell transplant recipients. Blood 2014;124(19):2921-9.

121. Mullane KM, Winston DJ, Wertheim MS, et al. Safety and immunogenicity of heat-treated zoster vaccine (ZVHT) in immunocompromised adults. J Infect Dis 2013;208(9):1375-85.

122. Winston DJ, Mullane KM, Cornely OA, et al. Inactivated varicella zoster vaccine in autologous haemopoietic stem-cell transplant recipients: an international, multicentre, randomised, doubleblind, placebo-controlled trial. Lancet 2018;391(10135):2116-2127.

123. Kaplan L, Daum RS, Smaron M, McCarthy CA. Severe measles in immunocompromised patients. Jama 1992;267(9):1237-41.

124. Machado CM, Goncalves FB, Pannuti CS, Dulley FL, de Souza VA. Measles in bone marrow transplant recipients during an outbreak in Sao Paulo, Brazil. Blood 2002;99(1):83-7. 125. Nakano T, Shimono Y, Sugiyama K, et al. Clinical features of measles in immunocompromised children. Acta Paediatr Jpn 1996;38(3):212-7. 
126. King JC, Jr., Vink PE, Farley JJ, Smilie M, Parks M, Lichenstein R. Safety and immunogenicity of three doses of a five-valent pneumococcal conjugate vaccine in children younger than two years with and without human immunodeficiency virus infection. Pediatrics 1997;99(4):575-80.

127. Gershman M, Staples J. Yellow Fever. In: Brunette G, editor. CDC Health Information for International Travel 2014. US Dept. of Health and Human Services. Centers for Disease Control and Prevention., ed. The Yellow Book. New York, USA: Oxford University Press Inc, 2014.

128. Gowda R, Cartwright K, Bremner JA, Green ST. Yellow fever vaccine: a successful vaccination of an immunocompromised patient. Eur J Haematol 2004;72(4):299-301.

129. Sicre de Fontbrune F, Arnaud C, Cheminant M, et al. Immunogenicity and safety of yellow fever vaccine in allogeneic hematopoietic stem cell transplant recipients after withdrawal of immunosuppressive therapy. J Infect Dis 2017.

130. Yax JA, Farnon EC, Cary Engleberg N. Successful immunization of an allogeneic bone marrow transplant recipient with live, attenuated yellow Fever vaccine. J Travel Med 2009;16(5):365-7. 131. Hayakawa K, Takasaki T, Tsunemine H, et al. Persistent seropositivity for yellow fever in a previously vaccinated autologous hematopoietic stem cell transplantation recipient. Int J Infect Dis 2015;37:9-10.

132. Patel NC, Hertel PM, Estes MK, et al. Vaccine-acquired rotavirus in infants with severe combined immunodeficiency. N Engl J Med 2010;362(4):314-9.

133. Palazzo M, Shah GL, Copelan O, et al. Revaccination after Autologous Hematopoietic Stem Cell Transplantation Is Safe and Effective in Patients with Multiple Myeloma Receiving Lenalidomide Maintenance. Biol Blood Marrow Transplant 2018;24(4):871-876.

134. Ogonek J, Kralj Juric M, Ghimire S, et al. Immune Reconstitution after Allogeneic Hematopoietic Stem Cell Transplantation. Front Immunol 2016;7:507.

135. Siber GR, Werner BG, Halsey NA, et al. Interference of immune globulin with measles and rubella immunization. J Pediatr 1993;122(2):204-11.

136. author N. CDC. General recommendations on immunization-recommendations 
of the Advisory Committee on Immunization Practices (ACIP). MMWR 2011;60(No. RR-2).

137. Makatsori M, Kiani-Alikhan S, Manson AL, et al. Hypogammaglobulinaemia after rituximab treatment-incidence and outcomes. Qjm 2014;107(10):821-8.

138. Horwitz SM, Negrin RS, Blume KG, et al. Rituximab as adjuvant to high-dose therapy and autologous hematopoietic cell transplantation for aggressive non-Hodgkin lymphoma. Blood 2004;103(3):777-83.

139. Harris AE, Styczynski J, Bodge M, Mohty M, Savani BN, Ljungman P. Pretransplant vaccinations in allogeneic stem cell transplantation donors and recipients: an often-missed opportunity for immunoprotection? Bone Marrow Transplant 2015;50(7):899-903.

140. Kumar D, Welsh B, Siegal D, Chen MH, Humar A. Immunogenicity of pneumococcal vaccine in renal transplant recipients--three year follow-up of a randomized trial. Am J Transplant 2007;7(3):633-8.

141. Storek J, Dawson M, Lim L, et al. Efficacy of donor vaccination before hematopoietic cell transplantation and recipient vaccination both before and early after transplantation. Bone Marrow Transplant 2004;33(3):337-46.

142. Wimperis JZ, Gottlieb D, Duncombe AS, Heslop HE, Prentice HG, Brenner MK. Requirements for the adoptive transfer of antibody responses to a priming antigen in man. J Immunol 1990;144(2):5417. 